\title{
Evaluating Multispectral Imaging for Assessing Bacterial Leaf Blight Damage in Indonesian Agricultural Insurance
}

\author{
Yuti Giamerti ${ }^{1, *}$, Chiharu Hongo $^{2}$, Daiki Saito ${ }^{3}$, Oliver Caasi ${ }^{4}$, Pepi Nur Susilawati ${ }^{1}$, \\ Masahiro Shishido ${ }^{4}$, I Putu Sudiarta ${ }^{5}$ I Made Anom Sutrisna Wijaya ${ }^{6}$, Koki Homma ${ }^{3}$ \\ ${ }^{1}$ Banten Assessment Institute for Agricultural Technology Indonesian Ministry of Agriculture, Ciruas \\ Serang, Banten 42182, Indonesia \\ ${ }^{2}$ Center for Environmental Remote Sensing, Chiba University, 1-33 Yayoi-cho, Inage-ku, Chiba-shi, \\ Chiba 263-8522, Japan \\ ${ }^{3}$ Graduate School of Agricultural Science, Tohoku University, 468-1 Aramaki Aza Aoba, Aoba-ku, \\ Sendai, Miyagi 980-8572, Japan \\ ${ }^{4}$ Graduate School of Horticulture, Chiba University, 648 Matsudo, Matsudo-shi, Chiba 271-8510, \\ Japan \\ ${ }^{5}$ Faculty of Agriculture Udayana University, Jl. P.B Sudirman Denasar Bali \\ ${ }^{6}$ Faculty of Agriculture Engineering Udayana University, Jl. P.B Sudirman Denpasar Bali.
}

\begin{abstract}
Bacterial Leaf Blight (BLB) is one of the main diseases in Indonesia that causes a $90 \%$ reduction in grain weight. Multispectral imaging may be used as a quick and effective method for damage assessment and is expected to utilize on agricultural insurance in Indonesia. Data were collected at the rainy season and dry season 2018 in Farmers rice field at Bali Province. Vegetation indices (NDVI, GNDVI, and VARI $\mathrm{I}_{\text {red-edge) }}$ was analyzed using QGIS 2.18 from multispectral images. Some vegetation index shows positive correlation with SPAD and negative correlation with

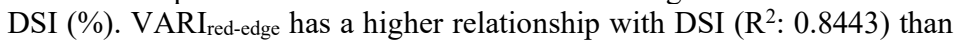
NDVI $\left(\mathrm{R}^{2}: 0.8291\right)$ and GNDVI $\left(\mathrm{R}^{2}: 0.5463\right)$ at the average value on each location, but the relation seems to be affected by that relation between SPAD and LAI. Further data and analysis are required.
\end{abstract}

\section{Introduction}

Bacterial Leaf Blight disease is one of the main rice diseases in Indonesia because BLB spread almost all over in the Indonesian region, and the severity has reached a high level especially in the rainy season. Rice can be attacked by BLB from nursery to harvest and is identified as a seed-borne pathogen [1]. Grain weight reduction due to BLB can reach $90 \%$ this happened because of the increase in infection rates [2].

BLB infected rice plants on the leaves through leaf wounds or natural holes in the stomata and damage chlorophyll. Sympthoms start from the edge of the leaves giving a stripped appearance, are grayish and became dry. Therefore, the severity of disease due to BLB possible to assess based on remote sensing image according to the attack severity.

${ }^{*}$ Coresponding author: yuti.giamerti@gmail.com 
Monitoring disease through remote sensing technology will be more efficient and make it easier to make quick decisions for pest and disease control in field. Direct detection of plants leaves infected with pests and diseases so that appropriate handling can only be carried out at specific infected locations. Several recent studies on remote sensing have found feature extraction and algorithms carried out at various scales, so that new possibilities for detecting pests and plant diseases from the air are known [3]. Furthermore, some studies clarify regarding the detection of the severity of BLB attack, it was found that vegetation indices can be used to detect crop disease seen in the canopy by estimating the chlorophyll contained in these plants $[4,5]$. This information supports the determination of the severity of plant diseases and the appropriate strategy in terms of assessing the damage in agricultural in Indonesia.

Indonesia has implemented agricultural insurance since 2013 to protect the farmers from losses due to damage (drought, flood, pest and diseases attack), but in the implementation of agricultural insurance, some obstacles faced by the Indonesian government include of lack of farmer awareness, difficult in dissemination of agricultural insurance, need a lot of human resources, and the assessment conducted by human eyes so would be time, cost and energyconsuming. Accordingly, remote sensing may be used as a quick and effective method for damage assessment formulation and monitoring for agricultural insurance policy claims [6, 7].

Recently, monitoring crops using Unmanned Aerial Vehicle (UAV) has been introduced into agricultural study [8]. The main advantages are simple operating with less manpower and imaging below the cloud cover [9]. The drone is also made a remote sensing image most appropriate for the smaller area and a small plot that the most used in rice fields in Indonesia. For this reason, it is important to consider a new method for assessing damage due to pest and diseases in Indonesian Agricultural Insurance, therefore the aim of this research is to evaluate multispectral imaging for assessing Bacterial Leaf Blight (BLB) damage.

\section{Method and data analysis}

Data were collected at the rainy season and dry season 2018 in Farmers rice field at Bali Province (Table 1). Rice disease intensity using Disease Severity Index (DSI) was measured and calculated by the pest observer at the same point with GPS, SPAD and LAI measurement. The number of observations points to collect the data is 30-50 point of each location.

Table 1. Location and data measurement at the rainy season and the dry season 2018.

\begin{tabular}{|l|l|l|}
\hline & \multicolumn{1}{|c|}{ Rainy Season } & \multicolumn{1}{c|}{ Dry Season } \\
\hline Location & Bali: & Bali: \\
& - Cemangi regency & - Sembung district, Badung regency (Ciherang, \\
& (Ciherang, 45-60 DAT $\left.{ }^{*}\right)$ & $75-80$ DAT) \\
& - Kekeran regency & - Kuwum district, Badung regency (Ciherang, \\
& (Ciherang, 45-60 DAT; 90-100 & 20-30 DAT and \\
& DAT) & $90-100$ DAT) \\
\hline $\begin{array}{l}\text { Ground } \\
\text { data }\end{array}$ & - Marking checkpoint by GPS & - Marking checkpoint by GPS \\
& - Measurement Leaf Area Index & - Measurement Leaf Area Index (LAI) in the \\
& (LAI) in the GPS point by LI- & GPS point by LI-COR LAI-2200 \\
& COR LAI-2200 & - Measurement leaf greenness by Minolta \\
& - Pest and disease intensity by pest & SPAD 502 \\
\hline Drone & observer & - Pest and disease intensity by pest observer \\
data & - Phantom 3 & - DJI Mavic Pro \\
& - Camera: Sequoia & - Camera: Sequoia \\
& Software to take an image by & - Software to take an image by drone: Precision \\
drone is Atlas flight & flight \\
\hline
\end{tabular}

${ }^{*}$ DAT: Day After Treatment 
Rice plant in the GPS point was observed and measured the harmfulness in the rice plant due to BLB damage using scoring, scoring that we used in this study based on technical instructions of pest observer, Indonesian Ministry of Agriculture on the Table2.

Table 2. The scoring method for BLB damage

\begin{tabular}{|l|c|c|c|c|c|c|}
\hline Score & $\mathbf{0}$ & $\mathbf{1}$ & $\mathbf{3}$ & $\mathbf{5}$ & $\mathbf{7}$ & $\mathbf{9}$ \\
\hline Percentage of BLB attacks on rice tillers in & \multirow{2}{*}{$0 \%$} & $1-$ & $6-$ & $26-$ & $51-$ & $76-$ \\
a clump & & $5 \%$ & $25 \%$ & $50 \%$ & $75 \%$ & $100 \%$ \\
\hline
\end{tabular}

Furthermore, using the score of BLB attack, Disease Severity Index (DSI) was calculated as:

$$
\operatorname{DSI}(\%)=\frac{\sum_{i=0}^{z}\left(n_{i} \times v_{i}\right)}{Z \times N} x 100
$$

Where $n_{i}$ is the class frequency or the number of tillers/part of the sample plant with a score of damage $\mathrm{V}_{\mathrm{i}}, \mathrm{V}_{\mathrm{i}}$ is the damage score at the sample plant (Score of rating class), $\mathrm{N}$ is a total number of observations and $\mathrm{Z}$ is the maximal disease index.

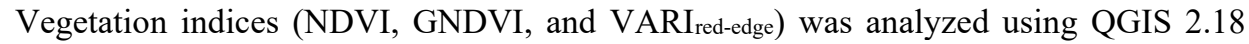
from multispectral images, these vegetation indices were calculated as:

$$
\begin{aligned}
N D V I & =\frac{N I R-R E D}{N I R+R E D} \\
G N D V I & =\frac{N I R-G R E E N}{N I R+G R E E N} \\
V A R I_{\text {red-edge }} & =\frac{R E D \_E D G E-R E D}{R E D \_E D G E+R E D}
\end{aligned}
$$

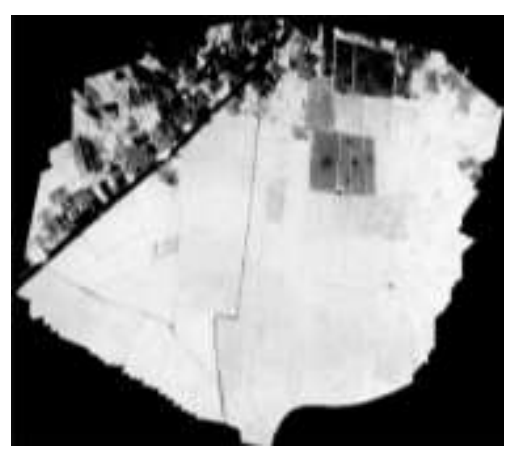

(a)

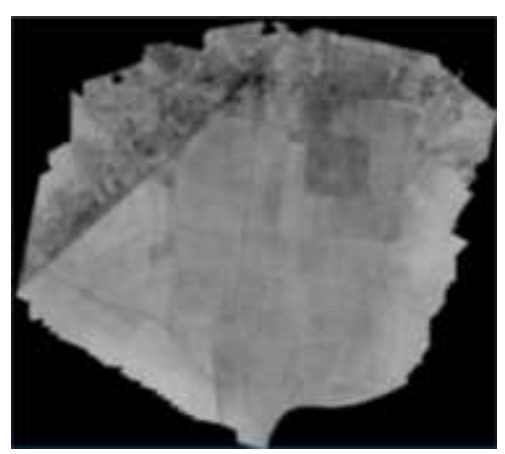

(b)

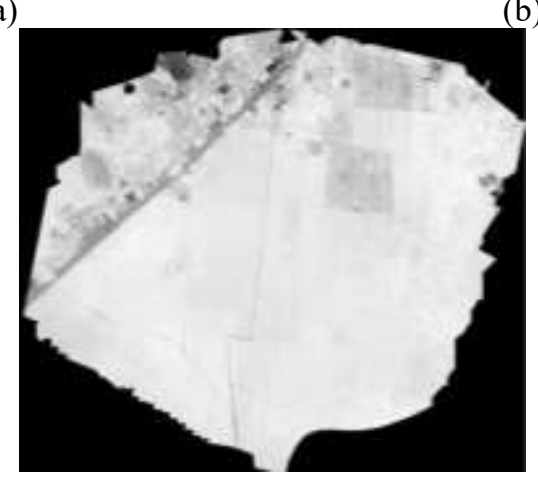

(c)

Fig 1. Vegetation indices images: (a) NDVI, (b) VARI red-edge, (c) GNDVI calculation from multispectral images. 


\section{Result and Discussion}

Xanthomonas oryzae pv. oryzae that causes BLB is the oldest and main bacterial rice disease in tropical and subtropical county [10], however, losses caused by BLB in the tropics is higher than in the subtropical region, a worldwide concern as well because that bacterial disease harm many rice fields regions of the world [11].

The differences of BLB attack in Bali between rainy season and the dry season is shown in Figure 2 which indicates that the most of BLB attack intensity at rainy season is on score 0 and in the dry season is on score 1 . Nevertheless, in the dry season even though there were BLB attacks, it was included in minor damage, while in the rainy season BLB attacks reached the highest score (score 9), more details can be seen in Table 3 and 4, the tables shows clearly that BLB damage in the rainy season is higher than in the dry season from DSI. In the rainy season Disease Severity Index (DSI) is higher than in the dry season especially at Sembung 1, higher DSI means the rice crops suffered more, this condition occurs due to environment factors in the rainy and the dry season affect the pathotype diversity of that bacterial [12], moreover, humidity in the rainy season is higher than the dry season, the air temperature in the rainy season also has the potential for the groth of BLB well.

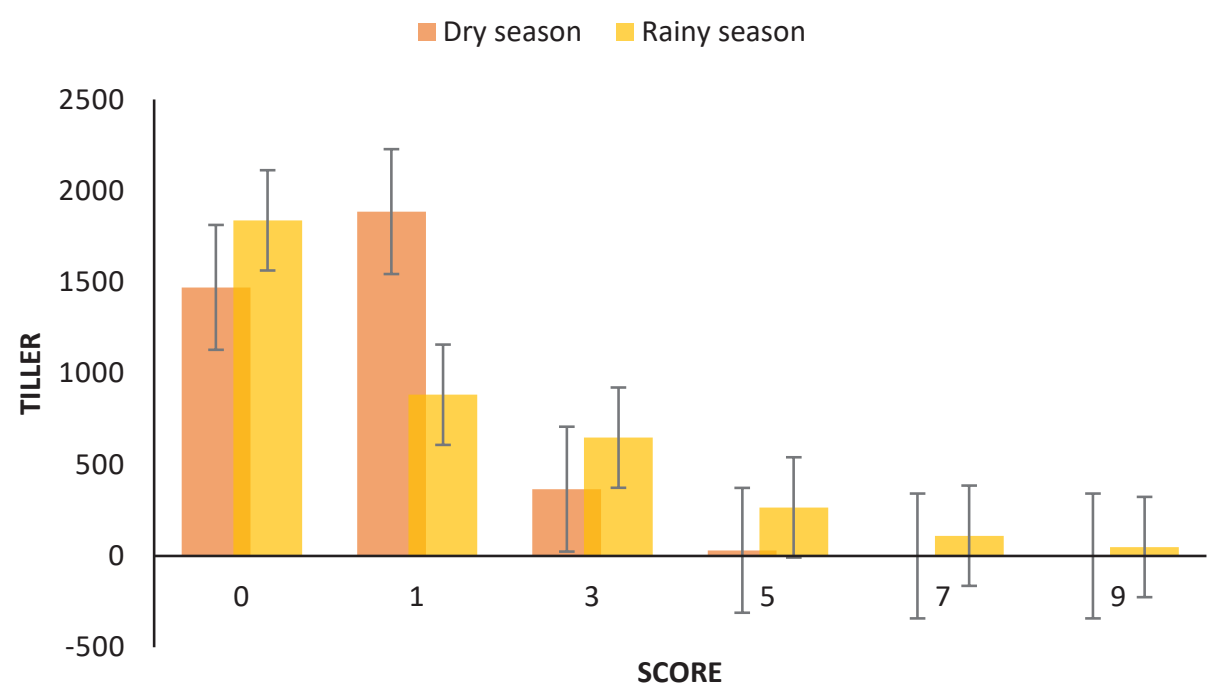

Fig 2. BLB damage in Bali in the rainy season and the dry season.

Table 3. BLB attack (tillers) in Bali at the rainy season.

\begin{tabular}{|c|c|c|c|c|c|c|c|}
\hline \multirow[t]{2}{*}{ Location } & \multicolumn{6}{|c|}{ Score } & \multirow{2}{*}{ DSI } \\
\hline & 0 & 1 & 3 & 5 & 7 & 9 & \\
\hline Sembung 1 & 159 & 171 & 249 & 116 & 95 & 48 & 33.2 \\
\hline Sembung 2 & 1279 & 251 & 74 & 36 & 3 & 1 & 4.67 \\
\hline Kuwum 1 & 299 & 107 & 55 & 35 & 8 & 0 & 12.04 \\
\hline Kuwum 2 & 101 & 354 & 273 & 79 & 5 & 0 & 21.95 \\
\hline
\end{tabular}


Table 4. BLB attack (tillers) in Bali at the dry season.

\begin{tabular}{|c|c|c|c|c|c|c|c|}
\hline \multirow[t]{2}{*}{ Location } & \multicolumn{6}{|c|}{ Score } & \multirow{2}{*}{ DSI } \\
\hline & 0 & 1 & 3 & 5 & 7 & 9 & \\
\hline Cemangi 1 & 110 & 229 & 173 & 16 & 0 & 0 & 16.5 \\
\hline Cemangi 2 & 116 & 478 & 76 & 10 & 0 & 0 & 11.7 \\
\hline Cemangi 3 & 277 & 354 & 44 & 5 & 0 & 0 & 8.9 \\
\hline Kekeran 1 & 256 & 317 & 16 & 0 & 0 & 0 & 7.0 \\
\hline Kekeran 2 & 419 & 167 & 44 & 0 & 0 & 0 & 5.1 \\
\hline Kekeran 3 & 243 & 350 & 13 & 0 & 0 & 0 & 7.3 \\
\hline
\end{tabular}

The rice crops suffered by BLB are also has a small SPAD value, the evidence was found at SPAD value on a Figure 3 that SPAD value at Sembung 1 is lower than the other places. Moreover, the DSI at Sembung 1 is higher than the other places. SPAD (chlorophyll meter) used for identification plant nitrogen or the greenness of leaf caused by damage. The rice leaves that were attacked by bacterial leaf blight indicates a change a leaf color, the greater the attack, the less greenness the leves are.

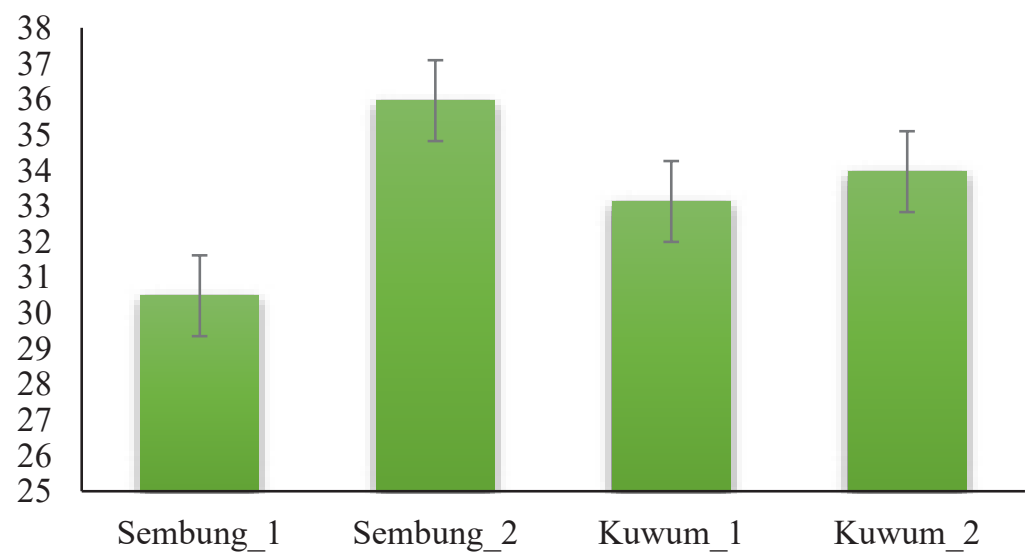

Fig 3. Average of SPAD value.

Relationship between DSI with SPAD and LAI has been analyzed to the evaluation of BLB damage on the rice field. The findings showed a negative relationship between DSI with SPAD and LAI which mean that the greater the BLB attack, the smaller the SPAD value and LAI.

DSI of BLB attack can be detected more through SPAD than LAI indicated by a higher relationship between SPAD with DSI $\left(\mathrm{R}^{2}: 0.7879\right)$ than LAI $\left(\mathrm{R}^{2}: 0.5783\right)$ as shown in Figure 4. Plant symptoms and physiological changes that are caused by pest and diseases, one of the symptoms is destruction of pigmen system. Crop damage due to BLB can cause destruction of chloroplast or other organelles, leading to change in pigment content.

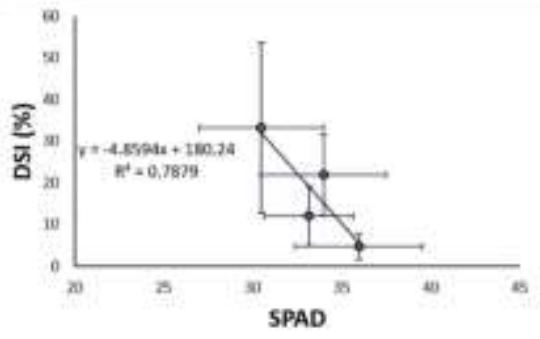

(a)

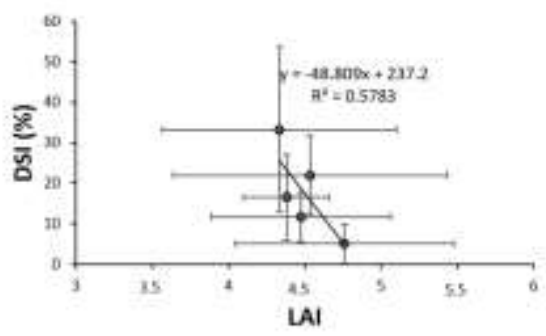

(b)

Figure 4. Relationship between DSI with (a) SPAD and (b) LAI. 
Each crop will show different symptoms in response to different diseases. Therefore, monitoring for damage due to pests and diseases through remote sensing requires a specific response that can be detected by specific sensors or certain vegetation indices so that each symptom can be recognized differently.

The vegetation index is often utilized to evaluate crop health. The evaluation result in this study showed that VARI $\mathrm{I}_{\text {red-edge }}$ is the most potent than the three vegetation indices (NDVI,

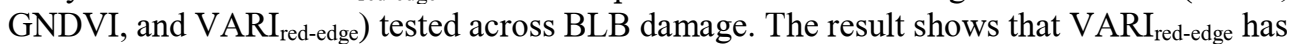
a higher relationship with DSI $\left(\mathrm{R}^{2}: 0.8443\right)$ than NDVI $\left(\mathrm{R}^{2}: 0.8291\right)$ and GNDVI $\left(\mathrm{R}^{2}: 0.5463\right)$ at the average value on each location as shown in Figure 5. Crop have certain plant reflection changes against crop diseases.

Red-edge region is determined as the spectral region between $80-750 \mathrm{~nm}$ there is a sharp change in the vegetation reflectance, the Red-edge channel is sensitive to the small change in the canopy, gap fraction, and senescence [13]. Some studies clarify regarding the detection of severity of BLB attacks trough satellite data, it was found that the Green Red Edge (GRE) index is the disease indices that the most sensitive to separate levels of BLB severity [14]. However, the relation between DSI and vegetation indices seem to be affected by the relation between DSI with SPAD and LAI, therefore, further data and analysis are required.

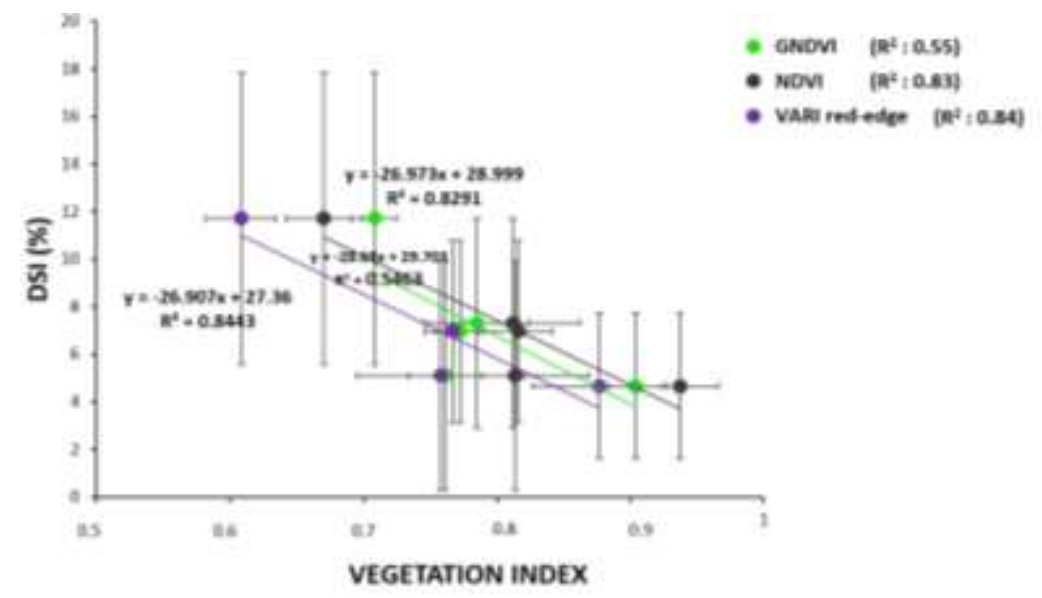

Fig 5. Correlation between SPAD and vegetation indices (NDVI, GNDVI, and VARI red-edge).

\section{Conclusions}

The detection of BLB on rice with UAV multispectral imagery may be more effective on damage assessment for Agricultural Insurance in Indonesia. We summarized that BLB attack in Bali in the rainy season is higher than in the dry season due to humidity is higher in the rainy season than the dry season and air temperature is potential for BLB growing well. DSI of BLB attack can be detected more through SPAD than LAI indicated by a higher relationship between SPAD with DSI $\left(\mathrm{R}^{2}: 0.7879\right)$ than LAI $\left(\mathrm{R}^{2}: 0.5783\right)$. VARI $\mathrm{I}_{\text {red-edge }}$ has a higher relationship with DSI $\left(\mathrm{R}^{2}: 0.8443\right)$ than NDVI $\left(\mathrm{R}^{2}: 0.8291\right)$ and GNDVI $\left(\mathrm{R}^{2}: 0.5463\right)$ at the average value on each location. This study can be used as additional information for further research in inventing other parameters that are most relevant in determining the geospatial information used in determining BLB attack in the rice field, especially for the benefit of Indonesian agricultural insurance policy claims. 
Acknowledgment. The research was founded by JST (Japan Science and Technology Agency) and JICA (Japan International Cooperation Agency) in a SATREPS (Science and Technology Research Partnership for Sustainable Development) Program, also Indonesian Ministry of Agricultur. Thank you to Ir. Resmayeti Purba for guidance in writing this paper.

\section{References}

1. Agustiansyah, Ilyas S, Sudarsono dan M Machmud. Jurnal Hama dan Penyakit Tumbuhan Tropika 13(1): 42-51 (2013)

2. Naveed S.A., Babar M., Arif A., Zafar Y., Sabar M., Ali I., Chragh M., Arif M. Afr. J. Biotechnol. 9(24):3549-3554 (2010)

3. Sankaran, S., Mishra, A., Ehsani, R., Davis, C. Comput. Electron. Agr. 72, 1-13 (2010)

4. Calderon M., Cortes J., Lucena C and P. Zarco-Tejada. J. Remote Sensing Environment. 139: 231-245 (2013)

5. Mahlein A. K., Rumpf T., Welke P., Dehne H. W., Plumer L., Steiner U and E. C Oerke. J. Remote Sensing Environment. 128: 21-30 (2013)

6. Gogoi N. K., Deka B. and L. C. Bora. Agriculture Rev. 10:1805-1835 (2018)

7. Martineli F., Scalenghe R. and S. Davino. J. Agronomy for Sustainable Development. 35(1): 1-25 (2015)

8. Zhang C and Kovacs J.M. Precis. Agric. 13. 693-712 (2012)

9. Floreano D and Wood R. J. Science, Nature 521. 460-466 (2015)

10. S.A. Hasan Naqvi, Rashida Perveen, Ummad ud Din Umer, Owais Malik, Ateew ur Rehman, Sajid Wazeer and Taha Majid. International Journal of Microbiology and Mycology. 2. 12-19 (2014)

11. Y. Xu, X.F. Zhu, M.G. Zhou, J. Kuang, Y. Zhang, Y. Shang, J.X. Wang. J. Phytopathol.

12. Sudir and Yuliani D. AGRIVITA Journal of Agricultural Science. 38(2):174-185. DOI:http://dx.doi.org/10.17503/ agrivita.v38i2.588 (2016)

13. M.N. Kahiu and N.P. Hanan. Journal of Geophysical Research: Biogeoscience 123 (1): 3-17 (2018)

14. Caasi O., Hongo C., Wiyono S., Giamerti Y., Saito D., Homma K and Shishido M. J. ISSAAS Vol. 26 No. 1: 1-16 (2020) 